\title{
Application of hypoxicators in the rowers' training
}

\author{
Neykov S. ${ }^{1 \mathrm{ABE}}$, Bachev V. ${ }^{\mathrm{AADE}}$, Petrov L. ${ }^{\mathrm{BCD}}$, Alexandrova A. ${ }^{2 \mathrm{ACD}}$, \\ Andonov A. ${ }^{1 \mathrm{AB}}$, Kolimechkov S. ${ }^{2,3 \mathrm{CD}}$ \\ ${ }^{1}$ Department of Theory and Methods of Sport Training, Coaches Faculty, National Sports Academy, Sofia, Bulgaria \\ ${ }^{2}$ Department of Physiology and Biochemistry, Coaches Faculty, National Sports Academy, Sofia, Bulgaria
}

Authors' Contribution: A - Study design; B - Data collection; C - Statistical analysis; D - Manuscript preparation; E - Funds collection

\begin{abstract}
Purpose:

Intermittent altitude exposure leads to improvements in aerobic performance and blood parameters of athletes. The variety of hypoxic devices and simulated altitude training models requires a detailed study of their effects to achieve the best results. The aim of this study was to investigate the effect of a four-week training camp at sea level conditions, combined with normobaric hypoxia, provided by hypoxicators during the night's sleep of the athletes.

Material: $\quad$ Sixteen rowers of the Bulgarian national team ( $17.13 \pm 0.83$ years old) were divided into a control group $(n=8)$ and an experimental group $(n=8)$ subjected to hypoxia for a period of four weeks. At the beginning and end of the training camp, anthropometric and hematological data were measured. A submaximal test on the Concept II rowing ergometer was performed, and the physical work capacity and anaerobic threshold were determined.

Results: $\quad$ The results showed: 1) a lack of significant changes in the aerobic performance after training camp, both within and between groups; 2 ) at the end of the training camp in the experimental group a statistically significant increase in hemoglobin concentration $(156.25 \pm 4.11$ vs $162.75 \pm 4.11 \mathrm{~g} / \mathrm{L}, \mathrm{p}<0.01)$ and erythrocyte count $(5.26 \pm 0.13$ vs $5.49 \pm 0.10 \mathrm{~g} / \mathrm{L}, \mathrm{p}<0.01)$ was observed.

Conclusions: The encouraging results regarding the higher increase in blood oxygen-carrying capacity in the experimental group did not lead to an increased working capacity. Further research should be provided in the search for optimal hypoxic training parameters, allowing not only a rise in hemoglobin concentration, but also the preservation of blood rheological properties.

Keywords: $\quad$ aerobic power, hemoglobin, hypoxia training, hypoxicator, rowers.
\end{abstract}

\section{Introduction}

Sports' training is a complex process for improving physical qualities and developing a high level of technical efficiency. In endurance sports success in performance is mainly determined by the rate of both oxygen transportation and oxygen utilization. However, after several years of training these rates often reach a level which can be sustained, but not increased [1]. Thus, a performance improvement of about $1-2 \%$ is a great challenge. One of the most effective ways for further development of functional capacities is altitude training [2].

It is well known that the decreased oxygen saturation of hemoglobin at high altitude causes activation of Hypoxia Inducible Factor 1 (HIF-1), which targets the activation of genes encoding erythropoietin (EPO) and the vascular endothelial growth factor. EPO stimulates red blood cell production in order to increase hemoglobin saturation and oxygen delivery. In addition, HIF-1 regulates the genes encoding the glycolytic enzymes and glucose transporters [3]. Since hypoxia triggers ergogenic adaptation, it is of great interest for athletes because it has the potential to improve their performance. Hypoxic training includes three models: live high and train high, live low and train high, and the new trend - live high and train low (LHTL). Altitude training could be related to some side effects, such as mountain sickness, pulmonary edema, cardiac

\footnotetext{
(c) Neykov S., Bachev V., Petrov L., Alexandrova A., Andonov A.,

Kolimechkov S., 2019

doi:10.15561/18189172.2019.0505
}

arrhythmias, and immune system dysfunction [4]. Many of these pathological states could be overcome [5] by using altitude simulation devices (hypoxicators), since they allow variations in simulated altitude and in hypoxic exposure duration. Substantial research has shown that intermittent altitude exposure via such devices leads to improvements in aerobic performance, ventilatory responses, and blood parameters [6] in a relatively short period of time [7]. Endurance athletes from many sports use hypoxic masks, tents, or chambers as part of their training programs. Moreover, hypoxic training is one of the few legal methods allowed by WADA to enhance physical endurance. The reduction of costs for traveling to and staying at high-altitude training sites, as well as avoidance of increased potential for illness due to chronic exposure to stress hormones [8,9], are other benefits of implementation of this type of training.

The existence of different devices, as well as a variety of simulated altitude training models, requires the detailed study of their effects to achieve the best results in training and competition. Therefore, the aim of this study was to investigate the effect of four weeks of training camp at sea level using hypoxicators to provide normobaric hypoxia during the night's sleep of the athletes, the LHTL model.

\section{Materials and methods}

Participants

Sixteen athletes from the Bulgarian national youth team in academic rowing of mean age $17.13 \pm 0.83$ years 
with mean height $183.75 \pm 4.61 \mathrm{~cm}$ and mean weight $77.79 \pm 7.42 \mathrm{~kg}$ took part in the study. The rowers had about 4-5 years of training experience. They have been winners of national junior championships, international junior rake regattas, and the Balkan championships, and they have achieved from $6^{\text {th }}$ to 12 th at the European Championships for Adolescents and Youths.

All participants received detailed information about the objectives and conducting of the study, and signed an informed consent form in accordance with the Helsinki Declaration of Human Research.

Study design

The study was conducted over a one-month period at the team's training camp at a 600-meter altitude dam. The rowers were divided into two groups: eight athletes were subjected to hypoxia during their night-time sleep (experimental group), and another eight athletes were selected as a control group. The hypoxia was introduced by masks, connected to MAG-20 hypoxicators (Mountain Air Generator 20, Higher Peak, USA) that simulated $1600 \mathrm{~m}, 2000 \mathrm{~m}, 2400 \mathrm{~m}$, and $2800 \mathrm{~m}$ altitude for a period of one week each (Figure 1).

The training program during the experiment was the same for both groups (Table 1). The rowers had three half days of rest - each Tuesday, Thursday and Sunday.

At the beginning and end of the training camp, the anthropometric data of the athletes (weight, height, and body composition) were measured and all participants performed a single submaximal test on the Concept II rowing ergometer. The test consisted of four three-minute exercise bouts separated by 30 s rest periods. The starting workload was $200 \mathrm{~W}$, and the subsequent loads increased by $40 \mathrm{~W}(240,280$ and $320 \mathrm{~W})$ - a modification according to Klusiewicz et al. [10]. At the end of each step, the heart rate was registered and during the rest periods the concentration of capillary blood lactate was measured. The test continued until a heart rate of $170 \mathrm{bpm}$, as well as a lactate concentration greater than $4 \mathrm{mmol} / \mathrm{L}$ were reached.

The test was used for determining PWC170 (Physical Work Capacity) and the anaerobic threshold - intensity of exercise at which lactate concentration reached $4 \mathrm{mmol} / \mathrm{L}$ (AnT-4). The following calculations were made: PWC170 per kilogram of body weight (PWC170/BW), heart rate at AnT-4 (HRAnT-4), and AnT-4 per kilogram of body weight (AnT-4/BW). The absolute and relative maximum oxygen consumption ( $\mathrm{VO} 2 \mathrm{max}$ and $\mathrm{VO} 2 \mathrm{max} / \mathrm{BW}$ ) and PWC170 were calculated by regression equations [10].

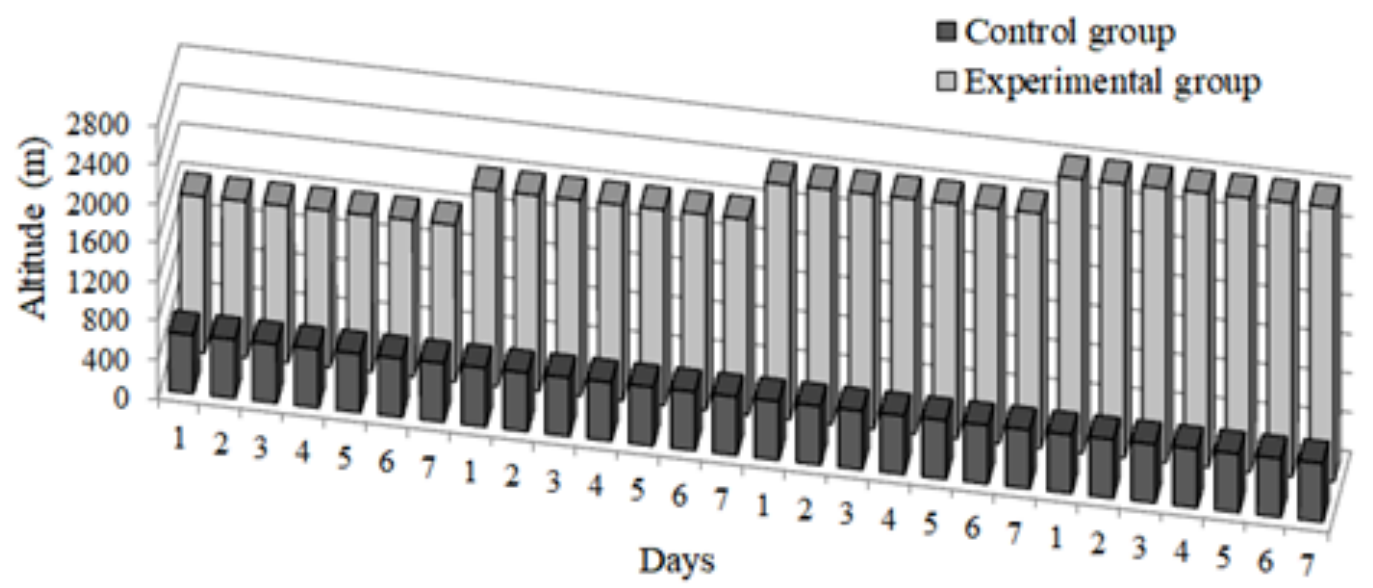

Figure 1. Experimental design. The simulated hypoxic exposure of the experimental group was eight hours every night.

Table 1. Rower's training program during experimental period

\begin{tabular}{|c|c|c|c|}
\hline Training session character & Training session content & $\begin{array}{l}\text { Part of the total } \\
\text { training volume }\end{array}$ & One week microcycle included: \\
\hline $\begin{array}{l}\text { A - mixed regime training } \\
\text { - aerobic lactic interval } \\
\text { training }\end{array}$ & $\begin{array}{l}40-60 \text { s work and } 120 \mathrm{~s} \text { rest } \\
\text { in } 3-4 \text { series }\end{array}$ & $34-35 \%$ & $\begin{array}{l}\text { 4-5 building training sessions. } \\
\text { Each training session lasted 90- } \\
100 \text { min. }\end{array}$ \\
\hline $\begin{array}{l}\text { B - aerobic regime, for } \\
\text { maintaining high level of } \\
\text { endurance }\end{array}$ & $\begin{array}{l}6 \times 2 \text { min repeated and } \\
\text { steady rowing at different } \\
\text { distances, or } 3 \times 4 \mathrm{~km} \text { rowing } \\
\text { in the same conditions }\end{array}$ & $53-55 \%$ & $\begin{array}{l}\text { 3-4 maintaining training sessions } \\
\text { for rowing technique. Each } \\
\text { training session lasted } 75-90 \\
\text { min. }\end{array}$ \\
\hline $\begin{array}{l}\mathrm{C} \text { - aerobic regime, for } \\
\text { maintaining high level } \\
\text { of physical fitness and } \\
\text { emotional recreation }\end{array}$ & $\begin{array}{l}\text { Non-specific training, such } \\
\text { as cross-country running, } \\
\text { stretching, gymnastics } \\
\text { exercises, and rowing } \\
\text { ergometer training }\end{array}$ & $10-12 \%$ & $\begin{array}{l}4-5 \text { general effect training } \\
\text { sessions. Each training session } \\
\text { lasted } 30 \mathrm{~min} .\end{array}$ \\
\hline
\end{tabular}


At the beginning and the end of the camp, venous blood samples were taken from the athletes.

Physical characteristics

Body Weight (BW) was measured within an accuracy of $0.05 \mathrm{~kg}$, and body composition was evaluated using the bioelectrical impedance method (Tanita 418, Japan). Body Height $(\mathrm{BH})$ was measured to the nearest $0.5 \mathrm{~cm}$ using a stadiometer. Body Mass Index (BMI) was calculated as BW (kg) divided by $\mathrm{BH}(\mathrm{m})$ squared. Hear rate was registered by the Polar $\mathrm{H} 7$ heart rate sensor (USA).

Biochemical analyses

Lactate concentration was measured in peripheral blood by using Lactate Pro 2, Japan.

Venous blood samples were taken by authorized medical staff, and were analyzed in a clinical laboratory for the following indicators: hemoglobin concentration, RBC count, hematocrit level, mean corpuscular volume $(\mathrm{MCV})$, mean corpuscular hemoglobin $(\mathrm{MCH})$, mean blood corpuscular hemoglobin concentration (MCHC), white blood cell (WBC) count and differential, platelet count and other derivatives, consisting of 22 indicators in total.

\section{Statistical analysis}

The data were analyzed statistically by using variance analysis; the reliability of the differences in the average values of the indicators was determined by Student's t-test for dependent and independent samples by SPSS statistical software (SPSS for Windows, version 16.0, 2008, SPSS Inc., Chicago, USA).

\section{Results}

Table 2 presents the basic anthropometric data of the athletes from the control and experimental groups. The average age of the rowers in the experimental group was $17.50 \pm 0.58$ years, while that in the control group was $16.75 \pm 0.96$ years. Average weight of the control group was $79.48 \pm 8.22 \mathrm{~kg}$ and of the experimental group 76.10 $\pm 7.29 \mathrm{~kg}$. The average stature of the control group was $183.63 \pm 5.15 \mathrm{~cm}$ and of the experimental group $183.88 \pm$
$4.80 \mathrm{~cm}$. There were no statistically significant differences between these parameters, although some of the indexes of the rowers from the control group were higher than those of the athletes from the experimental group, as follows: weight was higher by about $3 \mathrm{~kg}$, and mean fat percentage and relative muscle mass were higher by about $2-3 \%$. Only the average BMI of the control group was about $1 \mathrm{~kg} / \mathrm{m}^{2}$ lower. The anthropometric indicators did not show statistically significant differences before and after the one-month training period.

Table 3 presents the results of the submaximal functional tests performed. There were no significant changes in the parameters at the beginning and at the end of the training camp both within and between groups. A very good repeatability of the achievements of the tested individuals was observed, leading to a high degree of correlation between the results of the submaximal test before and after the training camp. The calculated correlation coefficients were as follows: for AnT-4 $r$ $=0.63311$, for HRAnT-4 $-\mathrm{r}=0.60$, for PWC170 and derivative calculated $\mathrm{VO}_{2} \max \mathrm{r}=0.88$, and for $\mathrm{VO}_{2} \max /$ $\mathrm{BW} \mathrm{r}=0.90$

The baseline values of the hematological parameters did not differ between both groups and were within normal limits, except for the relative lymphocyte count (LY\%) (Table 4), which was significantly lower in the control group vs the experimental group $(\mathrm{p}<0.05)$ before the training camp.

At the end of the training camp the blood indexes of the control group showed a slight, insignificant increase as the hemoglobin concentration rose from $151.00 \pm$ 3.92 to $154.5 \pm 4.20 \mathrm{~g} / \mathrm{L}$. During the period of testing the erythrocytes and hematocrit levels remained practically the same, and those of leukocytes increased slightly, albeit significantly, yet completely within the normal range (from $6.11 \pm 1.04$ to $6.75 \pm 0.83 \mathrm{~g} / \mathrm{L}, \mathrm{p}<0.05$ ) (Table 4).

In the experimental group at the end of the training camp a statistically significant increase in hemoglobin concentration (from $156.25 \pm 4.11$ to $162.75 \pm 4.11 \mathrm{~g} / \mathrm{L}$,

Table 2. Anthropometric data of the athletes from the control and experimental groups.

\begin{tabular}{|c|c|c|c|c|c|c|}
\hline Group & $\begin{array}{l}\text { Age } \\
\text { (years) }\end{array}$ & $\begin{array}{l}\text { Height } \\
\text { (cm) }\end{array}$ & $\begin{array}{l}\text { Weight } \\
\text { (kg) }\end{array}$ & $\begin{array}{l}\text { BMI } \\
\left(\mathrm{kg} / \mathrm{m}^{2}\right)\end{array}$ & $\begin{array}{l}\text { FAT\% } \\
\text { (\%) }\end{array}$ & $\begin{array}{l}\text { MM\% } \\
(\%)\end{array}$ \\
\hline & & $183.63 \pm 5.15$ & $79,48 \pm 8,22$ & $23,62 \pm 2,96$ & $14,90 \pm 4,08$ & $42,55 \pm 2,31$ \\
\hline
\end{tabular}

Control Group $\quad 16.75 \pm 0.96$

After

Before

Experimental Group
$79,65 \pm 8,87 \quad 23,66 \pm 2,98 \quad 12,78 \pm 3,68$

$43,63 \pm 2,3$

$183.88 \pm 4.80 \quad 76,10 \pm 7,29$

$22,47 \pm 1,29$

$16,38 \pm 6,39$

$40,48 \pm 4,4$
$17.50 \pm 0.58$ 
$\mathrm{p}<0.01$ ) and erythrocyte count (from $5.26 \pm 0.13$ to 5.49 $\pm 0.10 \mathrm{~g} / \mathrm{L}, \mathrm{p}<0.01$ ) were observed, and a slight but significant decrease in hematocrit levels (from $0.48 \pm 0.02$ to $0.47 \pm 0.02, \mathrm{p}<0.05$ ) was registered (Table 4 ).

At the start and the end of the training camp, in both groups, statistically significant, reciprocal changes in mean corpuscular volume (MCV) and mean corpuscular hemoglobin concentration (MCHC) were observed. The average volume of erythrocytes measured at the beginning vs the end of the training period decreased in both groups, while the average hemoglobin concentration in erythrocytes increased.

\section{Discussion}

The anthropometric indexes of the rowers in this study are comparable to those of international standard rowers. For instance, the data for the members of the Croatian national team (2008 year) of average age $17.6 \pm 0.4$

Table 3. Submaximal functional test results.

\begin{tabular}{|c|c|c|c|c|c|c|c|c|}
\hline Group & & $\begin{array}{l}\text { PWC170 } \\
\text { (W) }\end{array}$ & $\begin{array}{l}\text { PWC/BW } \\
\text { (W/kg) }\end{array}$ & $\begin{array}{l}\mathrm{VO}_{2} \max \\
(1 / \min )\end{array}$ & $\begin{array}{l}\mathrm{VO}_{2} \mathrm{max} / \mathrm{BW} \\
(\mathrm{ml} / \mathrm{kg} / \mathrm{min})\end{array}$ & $\begin{array}{l}\text { ANT } \\
\text { (W) }\end{array}$ & $\begin{array}{l}\text { ANT-4/BW } \\
\text { (W/kg) }\end{array}$ & $\begin{array}{l}\text { HRANT-4 } \\
\text { (bpm) }\end{array}$ \\
\hline \multirow{6}{*}{ Control Group } & & 274,77 & 3,47 & 5,30 & 67,14 & 303,24 & 3,84 & 180,71 \\
\hline & Before & \pm & \pm & \pm & \pm & \pm & \pm & \pm \\
\hline & & 59,48 & 0,73 & 0,45 & 7,7 & 13,87 & 0,33 & 16,12 \\
\hline & & 264,57 & 3,32 & 5,22 & 66,01 & 306,77 & 3,85 & 184,75 \\
\hline & After & \pm & \pm & \pm & \pm & \pm & \pm & \pm \\
\hline & & 41,35 & 0,37 & 0,31 & 5,68 & 38,84 & 0,25 & 5,69 \\
\hline \multirow{6}{*}{$\begin{array}{l}\text { Experimental } \\
\text { Group }\end{array}$} & & 252,71 & 3,31 & 5,13 & 67,70 & 288,08 & 3,8 & 180,23 \\
\hline & Before & \pm & \pm & \pm & \pm & \pm & \pm & \pm \\
\hline & & 35,12 & 0,21 & 0,27 & 3,62 & 20,63 & 0,27 & 7,43 \\
\hline & & 253,56 & 3,32 & 5,14 & 67,75 & 274,02 & 3,62 & 178,05 \\
\hline & After & \pm & \pm & \pm & \pm & \pm & \pm & \pm \\
\hline & & 43,57 & 0,34 & 0,33 & 2,8 & 15,65 & 0,23 & 12,39 \\
\hline
\end{tabular}

Table 4. Results of the hematological analyses of the rowers from the control and experimental group at the beginning and the end of the test period.

\begin{tabular}{|c|c|c|c|c|c|c|c|c|c|c|}
\hline Group & & $\begin{array}{l}\text { RBC } \\
\text { (T/L) }\end{array}$ & $\begin{array}{l}\text { Hgb } \\
\text { (g/L) }\end{array}$ & Hct & $\begin{array}{l}\text { MCV } \\
\text { (fL) }\end{array}$ & $\begin{array}{l}\text { MCHC } \\
(\mathrm{g} / \mathrm{L})\end{array}$ & $\begin{array}{l}\text { WBC } \\
\text { (G/L) }\end{array}$ & $\begin{array}{l}\text { LY\% } \\
\text { (\%) }\end{array}$ & $\begin{array}{l}\text { LY\# } \\
\text { (G/L) }\end{array}$ & $\begin{array}{l}\text { PIt } \\
\text { G/L }\end{array}$ \\
\hline \multirow{7}{*}{ Control Group } & \multirow{3}{*}{ Before } & 5,03 & 151,00 & 0,47 & 93,55 & 321,8 & 6,11 & 36,75 & 2.27 & 212,0 \\
\hline & & \pm & \pm & \pm & \pm & \pm & \pm & $\begin{array}{l} \pm \\
37\end{array}$ & \pm & \pm \\
\hline & & 0,30 & 3,92 & 0,01 & 6,14 & 10,21 & 1,04 & $\begin{array}{l}e^{2} / 4 \\
e b^{*}\end{array}$ & 0.61 & 32.83 \\
\hline & \multirow{4}{*}{ After } & 5,14 & 154,5 & 0,45 & 87,5 & 344,8 & 6,75 & 37,05 & & \\
\hline & & \pm & \pm & \pm & \pm & \pm & \pm & \pm & 2.54 & 232,0 \\
\hline & & 0,21 & 4,20 & 0,01 & 5,82 & 10,72 & 0,83 & 8,50 & \pm & \pm \\
\hline & & & & & $\mathrm{cb}^{* * *}$ & $\mathrm{cb}^{* * *}$ & $\mathrm{cb}^{*}$ & & & \\
\hline \multirow{8}{*}{ Experimental Group } & \multirow{3}{*}{ Before } & 5,26 & 156,25 & 0,48 & 91,98 & 325,0 & 5,76 & 45,73 & 2.6 & 204,0 \\
\hline & & \pm & \pm & \pm & \pm & \pm & \pm & \pm & \pm & \pm \\
\hline & & 0,13 & 4,11 & 0,02 & 1,9 & 6,98 & 0,93 & 5,71 & 0.33 & 34.01 \\
\hline & \multirow{5}{*}{ After } & 5,49 & 162,75 & 0.47 & 85,33 & 347.5 & & 46.1 & & \\
\hline & & \pm & \pm & & & & 6,58 & & 2.94 & 207.2 \\
\hline & & 0,10 & 4,11 & 50 & 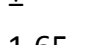 & 50 & \pm & & \pm & \pm \\
\hline & & $e b^{* *}$ & $e^{* *}$ & U,OL & 1,65 & 3,42 & 1,94 & & 0.45 & 33.56 \\
\hline & & $\mathrm{ca}^{*}$ & $\mathrm{ca}^{*}$ & & & & & & & \\
\hline
\end{tabular}

e - experimental group, $c$ - control group, $b$ - before, $a-a f t e r,{ }^{*}-p<0.05,{ }^{* *}-p<0.01,{ }^{* * *}-p<0.001$. Example: eb**

- statistically significant vs experimental group at $p<0.01$, before training camp. 
years $(\mathrm{n}=18)$ showed an average body weight of $86.1 \pm$ $4.1 \mathrm{~kg}$ and height average $188.9 \pm 3.6 \mathrm{~cm}$. Similar data were reported in the large anthropometric study of 383 (89\%) rowers in the 1997 World Rowing Championship, Hazewinkel, Belgium, where the non-finalists had an average weight of $80.6 \pm 5.0 \mathrm{~kg}$ and an average height of $186.3 \pm 6.1 \mathrm{~cm}$, and the finalists had an average weight of $84.8 \pm 7.1 \mathrm{~kg}$ and an average height of 189.3 $\pm 5.0 \mathrm{~cm}$, with an average age of $17.8 \pm 0.7$ years for all individuals tested [11]. Using the percentile tables of the latter study, the data of the rowers tested in this research can be evaluated as follows: the height in both groups, about $183 \mathrm{~cm}$, corresponded to P25; the average weight of the control group of $79.48 \pm 8.22 \mathrm{~kg}$ corresponded to $\mathrm{P} 50$, and the average weight of the experimental group of $76.10 \pm 7.29 \mathrm{~kg}$ corresponded to $\mathrm{P} 25$.

According to a review of the Italian rowing federation [12], the percentage body fat of rowers is very low, with average values of $11.55 \pm 2.31 \%$.

Furthermore, the percentage body fat of the individuals tested in this study (Table 2) was slightly higher than that of the Croatian rowing champions and members of the Croatian national team (2008 year), whose athletes had $12.9 \pm 2.1 \%$ of body fat [13]. However, the maximum oxygen consumption of the same group of rowers ( $62.5 \pm$ $4.7 \mathrm{~mL} / \mathrm{kg} / \mathrm{min}$ ), which was determined by performance of a maximum aerobic test, was a little lower in comparison to our respondents. The estimated average relative maximum oxygen consumption of the rowers tested in our study (about $67 \mathrm{~mL} / \mathrm{kg} / \mathrm{min}$ ) was in accordance with the published norms for field oarsmen [14], which corresponded to the maximum score - "High".

In regards to the estimated AnT-4, the data in published literature are scanty. To the best of our knowledge only two research papers track the changes in AnT-4 in LHTL method. In a study of Polish rowers with similar to the above-mentioned anthropometric data, the average value for AnT-4 of $307 \pm 41 \mathrm{~W}$ was found [15], which is very close to our results. However, the heart rate at AnT-4 in Polish rowers was lower, $164 \pm 9 \mathrm{bpm}$ compared to around $180 \mathrm{bpm}$ in our athletes. In the second work, volunteers were subjected to intermittent hypoxia, and although a significantly increased power output at the anaerobic threshold $(228 \pm 28 \mathrm{~W}$ to $239 \pm 24 \mathrm{~W}, \mathrm{p}=0.04)$ was observed, there were no significant changes in $\mathrm{VO} 2 \mathrm{max}$ and in the cycling exercise [16].

It should be mentioned that the submaximal test results obtained before and after the training camp demonstrated a high correlation. It seems that the application of this test is a good opportunity for longitudinal tracking of the functional condition of rowers without disturbing their training schedule.

The changes in the red blood count during hypoxic training are logically the most intriguing and therefore the most studied. In our experiment there were no differences between the control and the experimental groups at the beginning of the training camp, except in lymphocyte counts (LY\%). It is probably due to redistribution in the number of different leukocyte types as the baseline absolute lymphocyte count (LY \#) is practically the same (Table 4).

When comparing the hematological parameters at the beginning and at the end of the study a statistically significant rise in erythrocyte and hemoglobin concentrations in the experimental group was observed: from $5.26 \pm 0.13$ to $5.49 \pm 0.10 \mathrm{~T} / \mathrm{L}, \mathrm{p}<0.01$ for erythrocytes and from 156.25 \pm 4.11 to $162.75 \pm 4.11 \mathrm{~g} / \mathrm{L}, \mathrm{p}<0.01$ for hemoglobin. The differences in these parameters at the end of the study between the control and the experimental group were greater. Similar observations have been reported in a hypoxic training experiment of elite Nordic skiers, under the LHTL scheme, exposed to simulated hypoxia for 11 hours a day, in three stages of 6 days at 2500,3000, and 3500 meters above sea level respectively [17]. In the quoted study there were no changes in hematological parameters in the control group, in contrast to the experimental group, where the hemoglobin concentration increased from $147 \pm 8.0$ to $150 \pm 4.0 \mathrm{~g} / \mathrm{L}$ and the red blood cell count from $4.88 \pm 0.43$ to $5.08 \pm 0.30 \mathrm{~T} / \mathrm{L}$. However, regardless of the improvements in the blood count, no improvement in functional parameters was observed in these athletes. The VO2max in the experimental group decreased, albeit insignificantly from $61.7 \pm 4.4$ to $59.3 \pm$ $2.0 \mathrm{~mL} / \mathrm{kg} / \mathrm{min}$ [17]. In another study, where two groups of highly trained athletes were subjected to 8 hours per night for two consecutive nights a week over 3 weeks under either short-term normobaric hypoxia (simulating $3636 \mathrm{~m}$ altitude) or in normobaric normoxia, there was no improved aerobic or anaerobic performance, although short-term normobaric hypoxia exposure increased the levels of a number of hematological parameters [18]. Our results also did not show changes in VO2max at the end of the training camp.

In addition to the blood oxygen-transporting capacity the rheological properties of the blood should also be considered. Blood fluidity has been reported previously to positively correlate with aerobic working capacity, the performance time until exhaustion, and blood lactate response [19]. In addition to hemodynamic parameters, improvements in hemorheological parameters are likely to aid better performance. Increased blood fluidity may improve oxygen delivery to muscles during exercise in well-trained individuals [20].

Among the parameters tested by us at the end of the study, compared to the beginning, we observed in the experimental group a slight but significant hematocrit reduction from $0.48 \pm 0.02$ to $0.47 \pm 0.02$, which is contrary to an increased erythrocyte count (RBC) and increased hemoglobin, and is probably due to a decrease in the average volume of erythrocytes (MCV) (Table 4). These changes in MCV could represent the physiological principle for maintenance of favorable blood viscosity [21]. However, a recent study [22] demonstrated that high MCHC and low MCV had a negative impact on the deformability of erythrocytes and correlate with their increased rigidity. In this way the rheological properties of the blood deteriorate. The lack of progress in aerobic performance against the improved blood 
oxygen-transporting capacity, noted by us and by other authors [18], may be due to a reciprocal deterioration in the blood rheological properties associated with $\mathrm{MCV}$ reduction and MCHC increase, and thus, a difficult passing of erythrocytes through microcirculation. The negative impact of hypoxia on blood viscosity has been demonstrated on experimental animals that were subjected to 5 weeks chronic and intermittent ( 8 hours per day) hypoxia [23]. The results suggested that intermittent hypoxia and continuous hypoxia led to increased whole blood viscosity that impairs the functions of red blood cells and promotes platelet aggregation in rats.

\section{Conclusions}

Our results suggest that: 1) the submaximal rowing specific test used by us is suitable for studying the dynamics of AnT-4 and PWC170 without disturbing training schedules; 2) one-month training at low altitude, combined with 8 hours hypoxic application per night, does not increase the physical fitness performance in rowers with very high aerobic capacity; 3) the deterioration in the blood rheological properties could be a reason for the lack of improvement in working capacity, despite the increased blood oxygen-carrying capacity in the experimental group.

Further research should be carried out in search of optimal hypoxic training parameters that lead not only to a rise in hemoglobin concentration and erythrocyte count, but also preserve the rheological properties of blood.

\section{Acknowledgements}

This paper is the equal work of all authors. The authors declare no conflict of interest.

This study was supported by the National Sports Academy (NSA № - 681 / 07.04.2015, “Modern aspects of altitude training in athletes from sports endurance").

\section{Conflict of interests}

The authors declare that there is no conflict of interests.

\section{References}

1. Maestu J, Jurimae J, Jurimae T. Psychological and biochemical markers of heavy training stress in highly trained male rowers. Medicina Dello Sport. 2003; 56(2), 95-101. https://doi.org/10.2466/pms.2002.95.2.520

2. Wilber R L. Application of altitude/hypoxic training by elite athletes. J. Hum. Sport Exerc. 2011; 6(2), 271-286. https://doi.org/10.4100/jhse.2011.62.07

3. Solaini G, Baracca A, Lenaz G, Sgarbi G. Hypoxia and mitochondrialoxidativemetabolism.BiochimicaetBiophysica Acta (BBA) - Bioenergetics. 2010; 1797(6-7),1171-1177. https://doi.org/10.1016/j.bbabio.2010.02.011

4. Bailey M, Davies B. Physiological implications of altitude training for endurance performance at sea level: a review. British Journal of Sports Medicine. 1997; 31(3), 183-90. https://doi.org/10.1136/bjsm.31.3.183

5. Beidleman BA, Muza SR, Fulco CS, Cymerman A, Skrinar GS, Lewis SF, et al. Intermittent altitude exposures eliminate acute mountain sickness at $4300 \mathrm{M}$. Medicine \& Science in Sports \& Exercise 2003;35:S163. https://doi.org/10.1097/00005768-200305001-00896

6. Beidleman A, Muza R, Fulco S, Cymerman A, Sawka $\mathrm{N}$, Lewis $\mathrm{F}$, et al. Seven intermittent exposures to altitude improves exercise performance at $4300 \mathrm{~m}$. Medicine and Science in Sports and Exercise. 2008; 40(1), 141-148. https://doi.org/10.1249/mss.0b013e31815a519b

7. Rodríguez A, Casas H, Casas M, Pages T, Rama R, Ricart A, Ventura L, Ibáñez J, Viscor G. Intermittent hypobaric hypoxia stimulates erythropoiesis and improves aerobic capacity. Medicine \& Sciencein Sports \& Exercise. 1999;31(2), 264-268. https://doi.org/10.1097/00005768-199902000-00010

8. Walsh NP, Whitham M. Exercising in Environmental Extremes: A Greater Threat to Immune Function? Sports Medicine, 2006;36:941-76. https://doi.org/10.2165/00007256-200636110-00003

9. Walsh NP, Gleeson M, Pyne DB, Nieman DC, Dhabhar FS, Shephard RJ, et al. Position statement. Part two: Maintaining immune health. Exerc Immunol Rev, 2011;17:64-103.

10.Klusiewicz A, Borkowski L, Sitkowski D, BurkhardJagodzińska K, Szczepańska B, Ładyga M. Indirect Methods of Assessing Maximal Oxygen Uptake in Rowers: Practical
Implications for Evaluating Physical Fitness in a Training Cycle. Journal of Human Kinetics. 2016; 50(50), 187-194. https://doi.org/10.1515/hukin-2015-0155

11.Bourgois J, Claessens L, Vrijens J, Philippaerts R, Van Renterghem B, Thomis M, et al. Anthropometric characteristics of elite male junior rowers. Br J Sports Med. 2000; 34, 213-217.

12.Spataro A, Crisostomi S, Cifra B, Di Cesare A, Di Giacinto $\mathrm{B}$, De Blasis E, et al. The rowing ten years later. Medicina Dello Sport. 2009; 62(2), 209.

13.Mikulić P. Anthropometric and Physiological Profiles of Rowers of Varying Ages and Ranks. Kineziologija. 2008; 40(1), 80-88.

14.Klusiewicz A, Starczewski M, Ładyga M, Długołęcka B, Braksator W, Mamcarz A, et al. Section II- Exercise Physiology \&amp; Sports Medicine Reference Values of Maximal Oxygen Uptake for Polish Rowers. Journal of Human Kinetics. 2014; 44(44), 121-127. https://doi.org/10.2478/hukin-2014-0117

15.Klusiewicz A. Relationship between the anaerobic threshold and the maximal lactate steady state in male and female rowers. Biology of Sport. 2005; 22(2), 171-180.

16.Rodríguez A, Ventura L, Casas M, Casas H, Pagés T, Rama R, et al. Erythropoietin acute reaction and haematological adaptations to short, intermittent hypobaric hypoxia. European Journal of Applied Physiology. 2000; 82(3), 170-177. https://doi.org/10.1007/s004210050669

17.Robach P, Schmitt L, Brugniaux V, Nicolet G, Duvallet A, Fouillot $\mathrm{P}$, et al. Living high-training low: effect on erythropoiesis and maximal aerobic performance in elite Nordic skiers. European Journal of Applied Physiology. 2006; 97(6), 695-705. https://doi.org/10.1007/s00421-006-0240-7

18.Basset A, Joanisse R, Boivin F, St-Onge J, Billaut F, Doré J, et al. Effects of short-term normobaric hypoxia on haematology, muscle phenotypes and physical performance in highly trained athletes. Experimental Physiology. 2006; 91(2), 391-402. https://doi.org/10.1113/expphysiol.2005.031682

19.Brun F, Khaled S, Raynaud E, Bouix D, Micallef P, Orsetti A. The triphasic effects of exercise on blood rheology: which relevance to physiology and pathophysiology? Clinical 
Hemorheology and Microcirculation. 1998; 19(2), 89-104.

20.Baskurt O, Hardeman M, Rampling M, Meiselman J. (Eds.). Handbook of hemorheology and hemodynamics. Amsterdam: IOS Press; 2007.

21.Stäubli M, Roessler B. The mean red cell volume in long distance runners. European Journal of Applied Physiology and Occupational Physiology. 1986; 55(1), 49-53. https://doi.org/10.1007/BF00422892

22.von Tempelhoff F, Schelkunov O, Demirhan A, Tsikouras P, Rath W, Velten E, et al. Correlation between blood rheological properties and red blood cell indices ( $\mathrm{MCH}, \mathrm{MCV}, \mathrm{MCHC})$ in healthy women. Clinical Hemorheology and Microcirculation. 2016; 62(1), 45-54. https://doi.org/10.3233/CH-151944

23.Kang J, Li Y, Hu K, Lu W, Zhou X, Yu S, Xu L. Chronic intermittent hypoxia versus continuous hypoxia: Same effects on hemorheology? Clinical Hemorheology and Microcirculation. 2016; 63(3), 245-255. https://doi.org/10.3233/CH-151973

\section{Information about the authors:}

Neykov S.; http://orcid.org/0000-0002-3336-0454; svilen.neykov@abv.bg; Department of Theory and Methods of Sports Training, Coaches Faculty, National Sports Academy; National Sports Academy 1700, Sofia, Bulgaria.

Bachev V.; http://orcid.org/0000-0003-0481-2412; batchevv@yahoo.com; Department of Theory and Methods of Sports Training, Coaches Faculty, National Sports Academy; National Sports Academy 1700, Sofia, Bulgaria.

Petrov L.; http://orcid.org/0000-0003-1209-959X; dr.lubomir.petrov@gmail.com; Department of Physiology and Biochemistry, National Sports Academy; National Sports Academy 1700, Sofia, Bulgaria.

Alexandrova A.; http://orcid.org/0000-0002-7007-3665; a_alexandrova_bas@yahoo.com; Department of Physiology and Biochemistry, National Sports Academy; National Sports Academy 1700, Sofia, Bulgaria.

Andonov S.; http://orcid.org/0000-0003-3029-4778; andonov_svetoslav@yahoo.com; Department of Theory and Methods of Sports Training, Coaches Faculty, National Sports Academy; National Sports Academy 1700, Sofia, Bulgaria.

Kolimechkov S.; (Corresponding author); http://orcid.org/0000-0003-0112-2387; dr.stefan.kolimechkov@gmail.com; Department of Physiology and Biochemistry, National Sports Academy; National Sports Academy 1700, Sofia, Bulgaria.

Cite this article as:

Neykov S, Bachev V, Petrov L, Alexandrova A, Andonov A, Kolimechkov S. Application of hypoxicators in the rowers' training. Pedagogics, psychology, medical-biological problems of physical training and sports, 2019;23(5):239-245. https://doi.org/10.15561/18189172.2019.0505

This is an Open Access article distributed under the terms of the Creative Commons Attribution License, which permits unrestricted use, distribution, and reproduction in any medium, provided the original work is properly cited (http://creativecommons.org/licenses/by/4.0/deed.en).

Received: 23.07.2019

Accepted: 09.09.2019; Published: 17.09.2019 